Article

\title{
The Iron Age Settlement of Terronha (Viana do Castelo, Northwestern Portugal): Analysis of Ceramic and Lithic Materials in Context
}

\author{
Nuno Oliveira \\ FCT-SFRH/BD/138105/2018, Laboratory of Landscape, Heritage and Territory-Lab2PT, Department of History, \\ Campus de Gualtar, University of Minho, 4710-057 Braga, Portugal; ntco_arque@sapo.pt
}

Received: 29 November 2018; Accepted: 25 December 2018; Published: 3 January 2019

\begin{abstract}
This article's main objective is to present some results of a study carried out in Castro de Terronha, located in the Union of Cardielos and Serreleis parishes, county and district of Viana do Castelo, North of Portugal. This settlement was discovered and excavated in 2000 by the archeology company Perennia Monumenta under the scientific direction of Francisco Queiroga. The text focuses on the analysis of structures and indigenous ceramic and lithic remains discovered in sector A. The seven circular structures under study correspond to probable housing structures. Three of them have a vestibule attached. These would be about 5-6 $\mathrm{m}$ in diameter-a device of reasonable quality. Also found was a section of wall that ends abruptly, adjoining a great outcrop. Most of the ceramic specimens in articulation with the architectures revealed numerous similarities in morphological, technical and decorative terms with that of the Late Iron Age and the beginnings of Romanization in the Cávado Basin River. The set of remains suggests this settlement was involved in subsistence activities, metallurgy and trade.
\end{abstract}

Keywords: Northwest of Portugal; Iron Age; fortified settlement; Lima River Valley; material study; activities

\section{Introduction}

This site was mentioned for the first time by C. A. B. de Almeida in the scope of his doctoral thesis entitled "Povoamento Romano do Litoral Minhoto entre o Cávado e o Minho", where it is said that Castro da Terronha would have likely been an extension of Castro de S. Silvestre de Cardielos, located at higher altitude in the eponym mount [1] (p. 138). It was classified as an "agricultural hillfort" [1] (p. 139).

However, the site was excavated only during the construction of A27 (highway), which caused its partial destruction. Perennia Monumenta was in charge of the excavation under the scientific direction of Francisco Queiroga, and their aim was to detect structures using an emergency excavation-given that traces of occupation were found during the earth-moving work of the road. The excavation and affected area were of $8.190 \mathrm{~m}^{2}$ [2] (p. 2).

The direction of excavation was west-east. (Figure 1) The excavation took place between February and May of 2000 and encompassed a set of seven sectors distributed along the south-southeast of Monte de S. Silvestre and were named sectors A, B, C, D, E, F and G. Sector A is located next to the wall on the west side, Sector B is located east to the aforementioned sector and in near proximity to it, Sector C is located northeast to the aforementioned, Sector D is located south to the aforementioned, Sector E is on the northwest side of the previous sector where the wall was found, Sector F is located southwest to the aforementioned and lastly Sector $G$ is located in the southernmost tip of this settlement, probably already outside of the wall perimeter [2] (p. 3). 
Despite these interventions, nothing has been published about these excavations that substantiate this work until now. The intention of this paper is to characterize this settlement using the structures and spoil found in sector A.
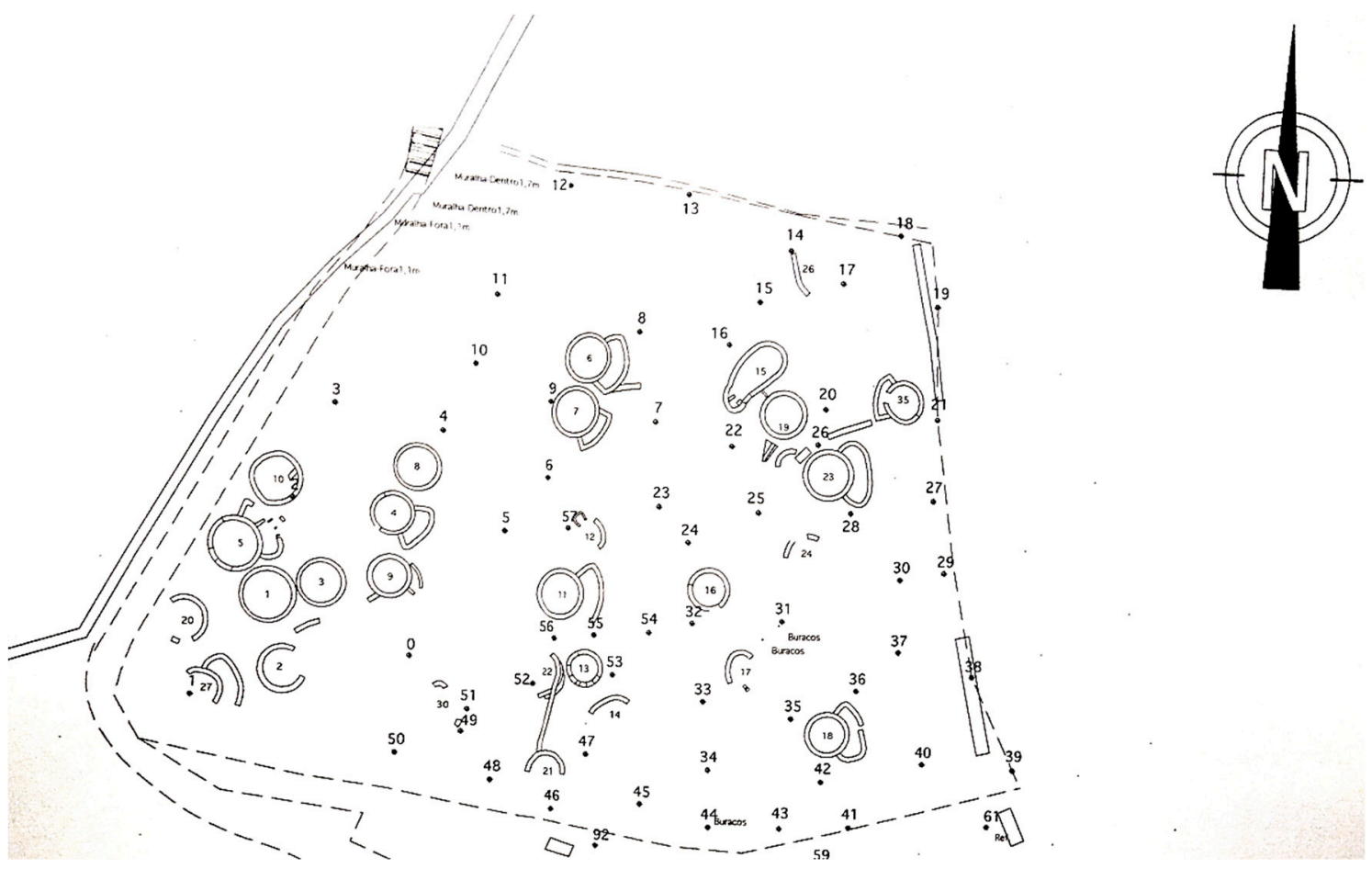

Figure 1. Topographic plan of the excavated area of the Settlement of Terronha. Scale 1:500 (adapted, Queiroga, [2]).

\section{Location and Physical Context}

This settlement was located in Lugar do Monte, União de Freguesias de Cardielos e Serreleis, county and district of Viana do Castelo. Its geographical coordinates, in degrees, minutes and seconds, in the WGS 84 system, are: $41^{\circ} 43^{\prime} 01.33^{\prime \prime} \mathrm{N}, 8^{\circ} 44^{\prime} 45.01^{\prime \prime} \mathrm{W}$ (Figure 2a).

It is located in a small end of a spur at the bottom of the south-south-east part of Monte de São Silvestre, corresponding to the south end of the Serra de Perre. The site is up the mouth of the stream Nogueira, affluent to the right bank of Rio Lima. It does not stand out much, having only $120 \mathrm{~m}$ as a maximum altitude.

From a geological perspective, the local substrate corresponds to the complex schist-granitic-migmatitic, composed of eruptive rocks of kaolin granitic of coarse grain or medium to gross that exists in abundance. This analysis is based on the Portuguese Geological Map, excerpt of sheet $5 \mathrm{~A}$, scale 1:50,000, 1970. However, in the proximity of this settlement there is an area of micaceous schists, as well as alluviums from Nogueira stream and Rio Lima. There are mining resources less than $3 \mathrm{~km}$ north and northeast, where several primary tin deposits are found (Figure $2 \mathrm{~b}$ ). 


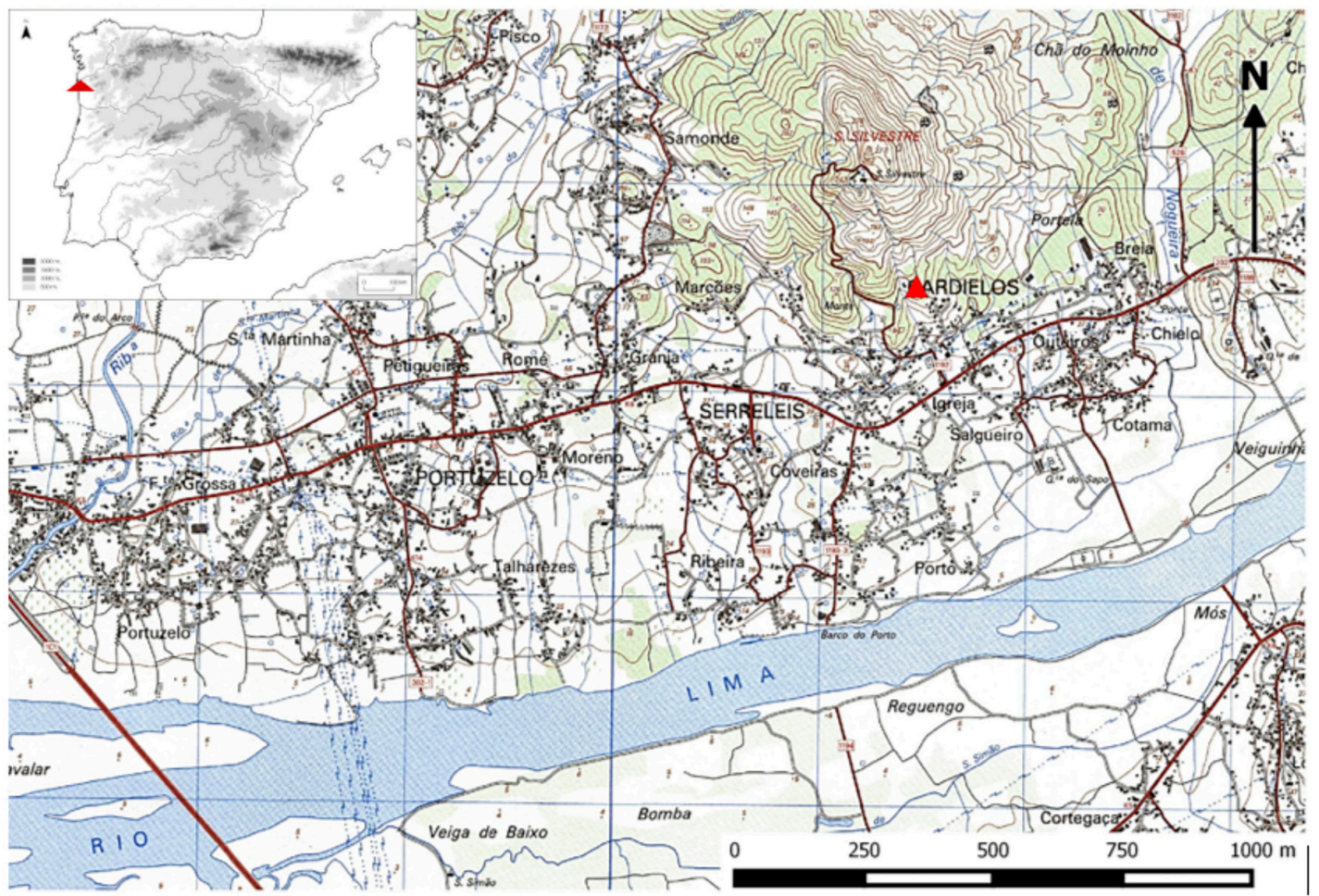

a)

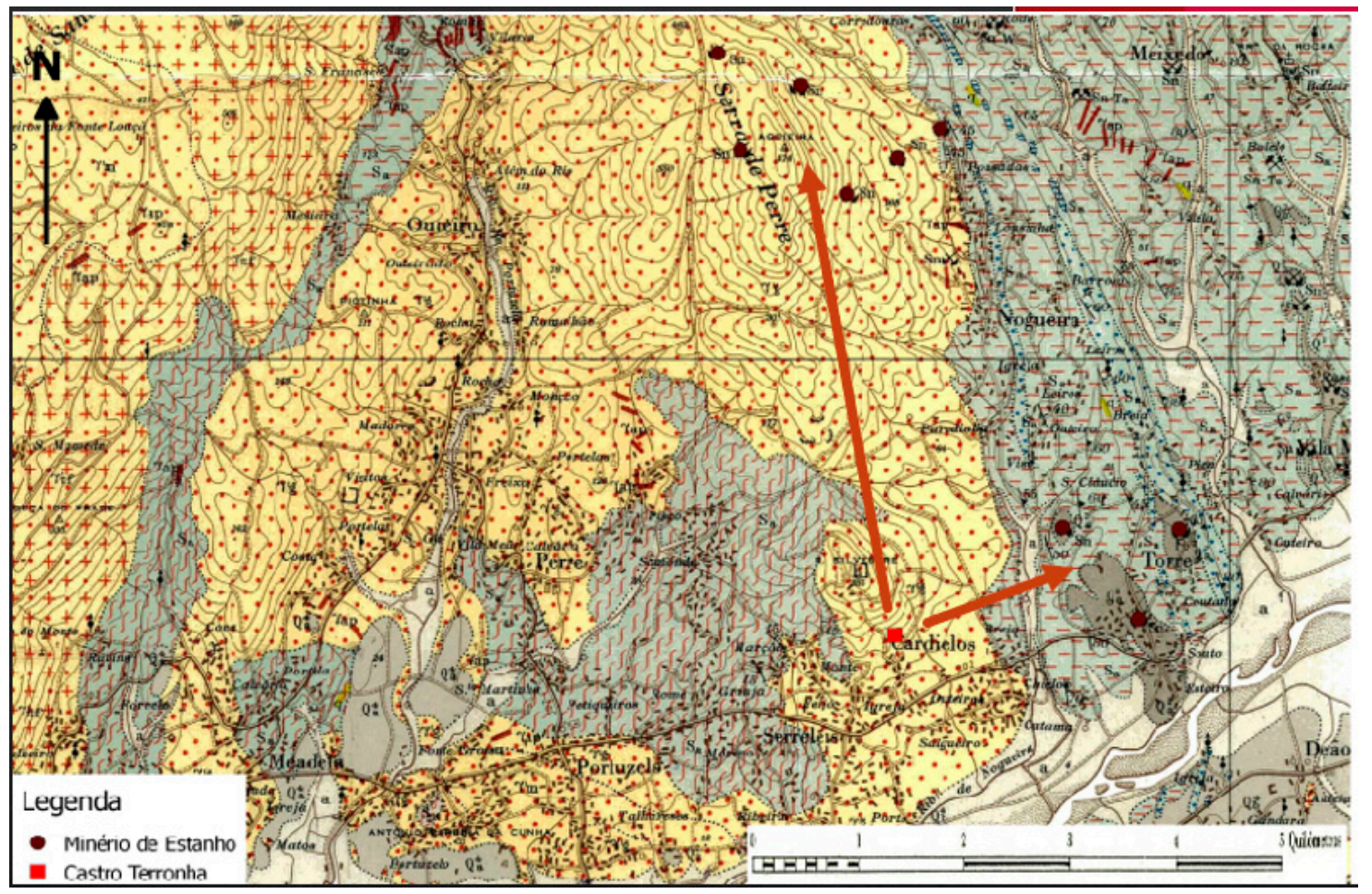

b)

Figure 2. (a) Location of the settlement in the Portuguese Military Map, excerpt of sheet 40, scale 1:25,000, IGEOE, 2015, 3rd edition; (b) Location of the settlement in the Portuguese Geological Map, excerpt of sheet 5 A, scale 1:50,000, 1970, (DGMSG) and its position regarding existing tin deposits. 


\section{Archaeological Context}

This settlement is very close to the other two mentioned for Monte de S. Silvestre by C.A.B. Almeida [1] (pp. 138-139) and Francisco Queiroga [2]: Castro do Monte (in a spur about $300 \mathrm{~m}$ northeast of Terronha and $130 \mathrm{~m}$ high) and Castro de São Silvestre (at the top of the mount and at the beginning of the west part and about $1 \mathrm{~km}$ north). It is likely for Terronha to correspond to a lower platform of Castro do Monte, as Francisco Queiroga [2] has suggested, but only future excavations will clarify this assumption. There are reports of petroglyphs in the southeast and east parts of the Monte de S. Silvestre: these are cravings of Breia 1,2 and 3 with the Atlantic style [3]. In Breia 1, the author agrees that there are additions of equidae, which may be from the Iron Age, added to older markings, which originate in the Neo-Chalcolithic era.

\section{Methodology of Excavation and Laboratory Study}

As for methodology of excavation and according to Francisco Queiroga [2] (pp. 3-4), due to the condition of the ground and the extension of area to excavate, rather than a grid system it was implemented a set of dots, implanted in the rock outcrop, which constituted points of reference. The excavation followed the method of pickling by natural layers. In Sector A, a tractor was used to remove dirt from the excavation, which was then placed in the perimeter of the site. Technological criteria as well as the table of ceramic models of the Iron Age by Martins [4,5] were used to study the ceramic materials.

Regarding the formal study, all of the ceramic fragments were analysed in an attempt to determine which part of the larger piece it could possibly belong to (lip, shoulder, body, base and handle). As for the handles, there was an attempt to establish its section (oval, in ribbon, pentagonal, triangular, rectangular, among others) and its types of grip (horizontal, vertical and diagonal), according to the criteria outlined by Ramos and Martins [6].

The criteria of Brudenell and Cooper [7] were used in regards to the study of the fragmentation levels of the ceramic elements, which will also be object of analysis in this work. This criteria mentions that ceramic fragmentation levels and the erosion index may contain answers and information about deposit and post-deposit phenomena of a specific layer or context, in a given archaeological site. These authors subdivide the fragments in small $(<4 \mathrm{~cm}$ ); medium (between 4 and $<8 \mathrm{~cm}$ ) and big $(>8 \mathrm{~cm})$. To study the erosion index, it was considered if the fractures were angular or eroded.

The formal table of Silva and Oliveira [8] was used to study the cossoiros or loom of weights.

\section{Excavation of Sector A}

This sector corresponds to an excavation of about $512 \mathrm{~m}^{2}$, which made the discovery of a variety of stony structures and several ceramic and lithic spurs possible.

\subsection{Structures}

A wide range of circular structures was found in this sector, most likely for habitation purposes, as well as a part of a wall.

Observing the classification given by Queiroga [2], seven houses were detected, termed here as: No. 1, No. 2, No. 3, No. 5, No. 10, No. 20 and No. 27 (Figure 3). The following description of the construction of each of the structures was based on the field report of Francisco Queiroga [2]. 


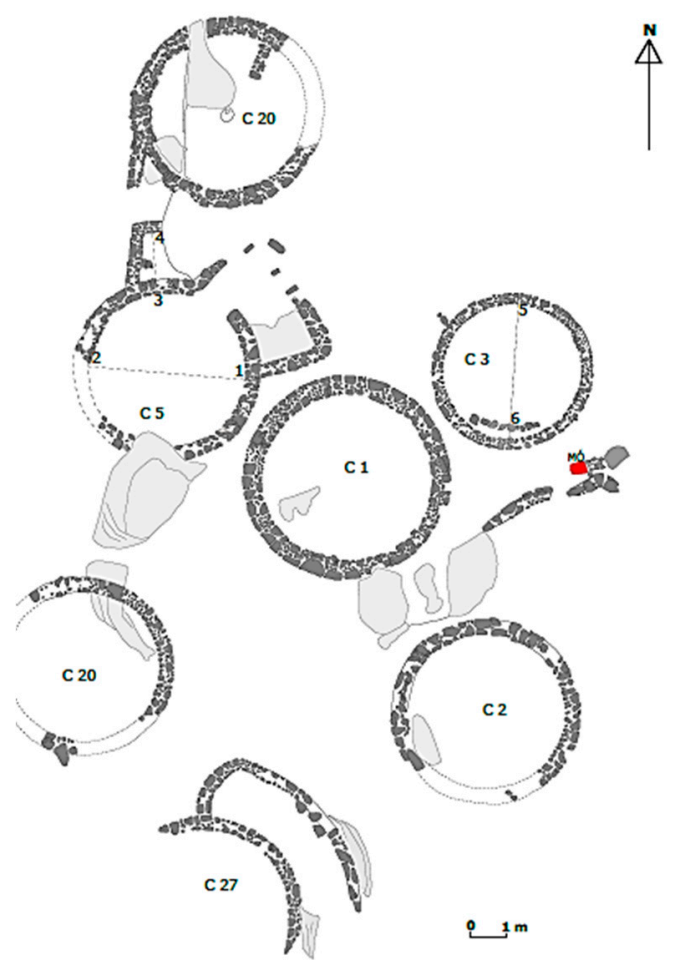

Figure 3. Diagram of the structures found in Sector A (adapted, F. Queiroga, [2].

House 1 was circular, characterized in that it was built by a double wall, with a diameter of about $6 \mathrm{~m}$ and having the remains of a compact floor in gravel in its interior. The wall was comprised of granitic blocks of bigger dimension and small-size pebbles used to fill in the interstices. This set was linked together by a weak mortar made of soil and clay. The blocks showed traces of peak at its ends.

House 2 was vastly destroyed, but it would have been circular. The foundation of its double wall was set directly on the granitic outcrops, having no traces of the level of occupation as well as of the entrance.

House 3 was circular with double walls and had distinct devices in the interior and exterior. On the south side, parallel to the wall, there was an internal stony alignment. The space for the indoor fireplace was delimited still in this structure, materialised by a clearly calcined clay stain. It was found near the north wall (Figure 4).

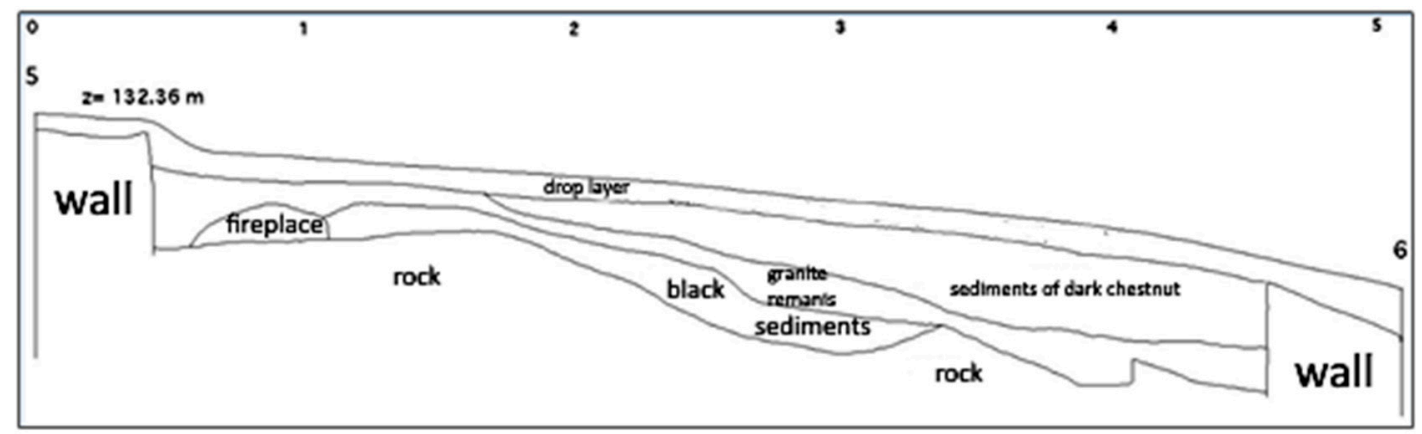

Figure 4. Profile of the east side of the interior of House 3 (adapted from Queiroga [2]).

House 5 was circular with a diameter of about $5.5 \mathrm{~m}$ and open towards north-northeast, and was built by a double wall that attached itself to an outcrop on the south side. From north to east, there was a 50-cm-wide vestibule. (Figures 5 and 6). 


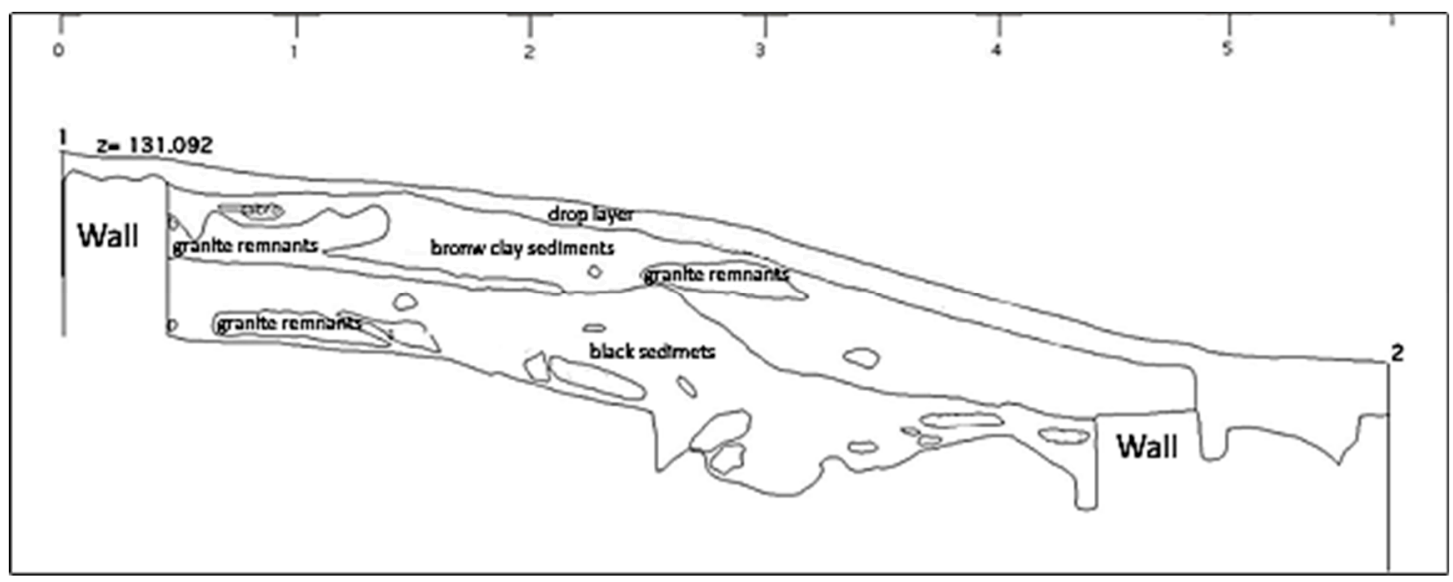

Figure 5. Profile of the north side of the interior of House 5 (adepted from Queiroga [2]).

In front of the entrance, already on the outside, there was a small sump or basin open in the rock, elongated, which was interpreted by Queiroga [2] as being a small drinker for small animals.

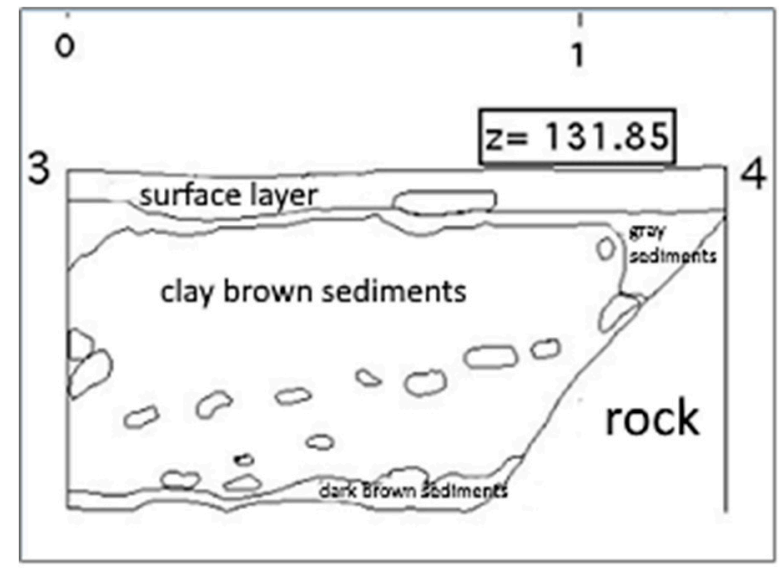

Figure 6. Profile of the interior of the vestibule of House 5 (adepted from Queiroga, [2]).

House 10, circular and with a diameter of about $5.70 \mathrm{~m}$, was also built with a wall of irregular equipment, with small and medium size pebbles and blocks. In its interior, and attached to the northeast wall, there is a low wall about $1 \mathrm{~m}$ in length. Despite it being a subsequent addendum to the exterior wall, it corresponds to the only level of occupation found here. In this house, there might have been a gravelly floor, documented by a layer of gravel and floor fragments. A stone was found at the core of this building, having a sub-quadrangular shape to support the pole that was assumed it would support the coping. Another low wall was also found on the outside, which aligns with the vestibule's flap of House 5. This was according to the field report of Francisco Queiroga [2].

House 20, also circular, was vastly destroyed. It had a diameter of about $4.30 \mathrm{~m}$ and $40 \mathrm{~cm}$ in width and was built with a wall made of small stones. The remains showed that it set directly on the outcrop.

House 27 was circular, with a diameter of about $4 \mathrm{~m}$ and had a vestibule between the north and east quadrants, although it is not known the direction of its entrance. Its wall, which was set on the rock, had an irregular equipment and was formed by medium- and small-size pebbles and blocks. A fragment of floor or grout was found in the interior of this structure. 
There was a small wall, south to Houses 1 and 3, of an unknown purpose and what seems to be a fragmented livestock building, which appeared around House 20. It is made of schist (raw material abundant in this region) and is $10.2 \mathrm{~cm}$ long and $8.9 \mathrm{~cm}$ wide (Figure 7).

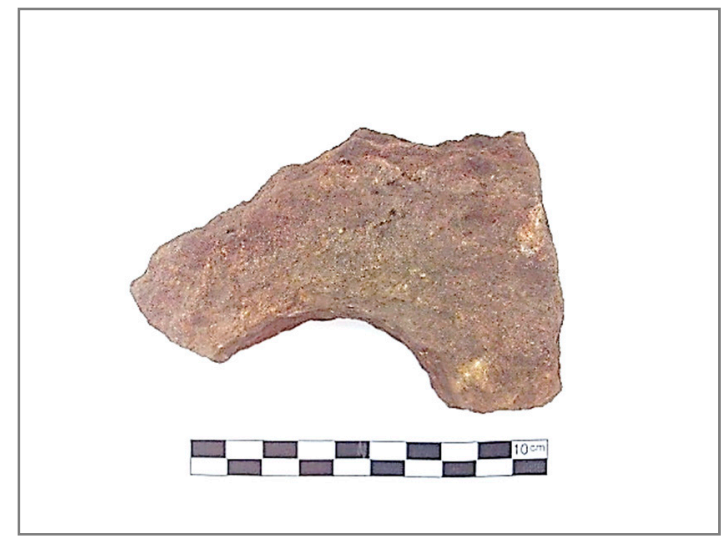

Figure 7. Possible livestock building (?).

Finally, regarding the wall, an extensive section of $85 \mathrm{~m}$ in length was uncovered, which was directed from northeast to southwest, later curving towards west in an area of superficial boulders and of considerable slope. In its path, it leaned toward several outcrops. It had an irregular width (between 2 and $3.5 \mathrm{~m}$ ) with the device being composed of medium and big size stony granitic blocks and was filled with thin rocks. It ended, abruptly, and south to which was assumed to be the entrance. The wall was remade in its internal side, where the paved path of the old road overlaps and ends in the sanctuary of São Silvestre (Figure 8).

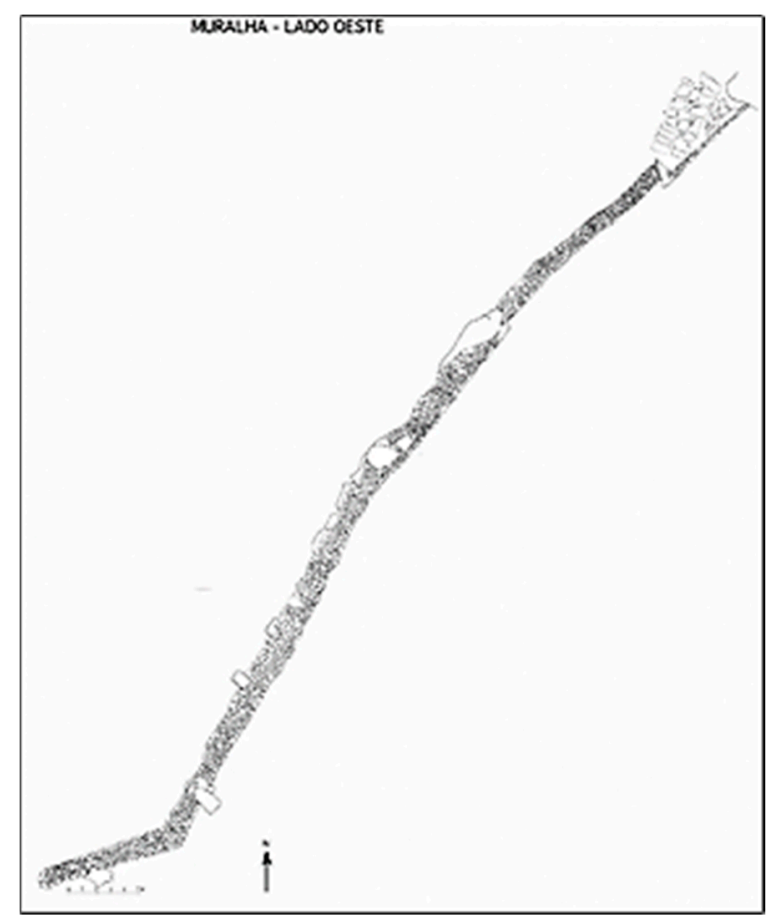

Figure 8. Plant of part of the excavated stone walls (according to Queiroga [2]).

A fragment of clay floor was found next to the wall, perhaps adorned or with negatives of plant elements (Figure 9). 


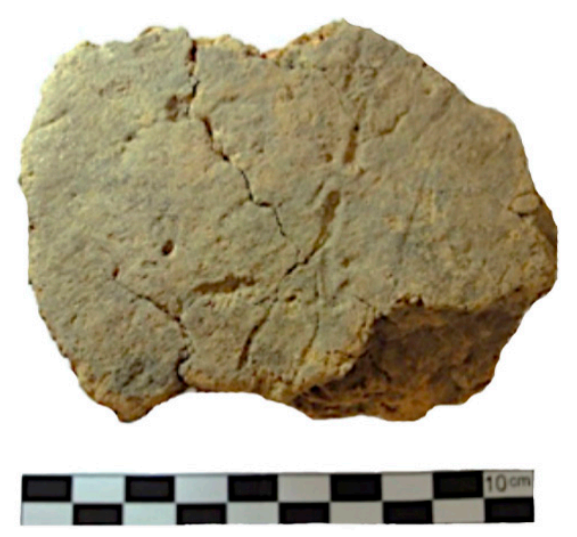

Figure 9. Fragment of floor found next to the wall.

\subsection{Spoil}

The spoil studied herein comprises indigenous pottery and some lithic ceramic fragments. Metallic materials and materials associated with metallurgy are not part of this work, as they will be published by Francisco Queiroga. It is registered at Museu D. Diogo de Sousa, Braga.

\subsubsection{Ceramic Spoil}

The ceramic set being analysed comprised 1171 fragments, of which 152 lips, 918 walls parts, 91 bases, nine handles and one loom weight.

The ceramic found is, technically speaking, mostly handmade (1113 fragments), with the remainder 58 fragments being made by wheel. The pastes were, in most cases, micaceous (1130 fragments-96\%), with nonplastic, relatively calibrated elements of medium and small magnitude. The sandy pastes correspond to only $4 \%$ of the total. The texture of the analysed fragments is, for the most part, medium and thin (569 and 526 fragments, respectively). Cooking tends to happen in a reducing environment (983 fragments-84\%), therefore the containers show brown colouring. The remaining $16 \%$ are oxidants, well cooked and with orange, yellow and beige colouring. The pastes presents were studied only by macroscopic analysis because, unfortunately, there were neither financial resources nor time for physical and chemical analyses of the ceramics.

The fragmentation index is somewhat elevated, since the majority $(52 \%)$ of the fragments have between $<3$ and $<7 \mathrm{~cm}$, according to the scale Brudenell and Cooper [7]. However, only 275 fragments $(23 \%)$ had relatively rolled edges, meaning there were not many changes and transportation of the fragments after they were abandoned in this location. Therefore, the elevated fragmentation index shown should be explained by the large percentage of micaceous containers, more prone to breaking than sandy pastes.

Morphologically speaking, a variety of shapes was studied, according to the table of shapes of Manuela Martins (1990).

It was possible to identify 144 shapes out of the 152 lips studied. Among them, 56 pots were counted and were used for different types of food storage and transportation, with diameters bigger than $25 \mathrm{~cm}$; 48 little pots (potinhos/púcaros), among them two little pots with a handle (púcaros) (small containers used to serve and consume food and beverages, as well as for cooking); 16 bowls (malgas) and 11 little bowls (tigelas) (to prepare, cook and serve food); two pots with handles inside (panelas de asa interior) to cook food; six pans with an ear handle (panelas de asa em orelha) (presumably to cook food); and five big pots (talhas), which were thought to have been used to store food, given its diameter and characteristics (Figure 10).All the pottery shapes in addition to the English translation, also the original name was placed in Portuguese, in brackets. 


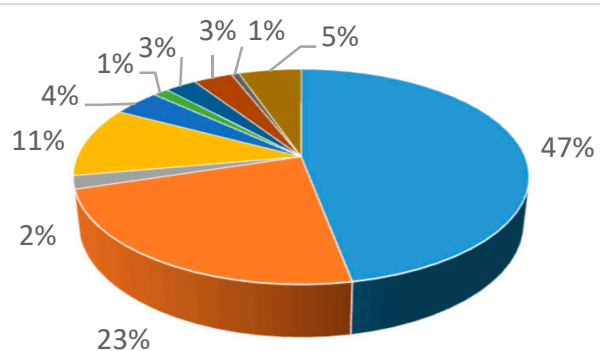

$$
\begin{array}{lll}
\text { - Pots } & \text { - Little Pots } & \text { - Little Pots with handle } \\
\text { - Bowls } & \text { - Little Bowls } & \text { - Pots with handles inside } \\
\text { - Pan with a ear handle } & \text { - Big Pots } & \text { - Cossoiro } \\
\text { - Indeterminated } & &
\end{array}
$$

Figure 10. Quantity of shapes discovered in Sector A.

Among the pots, the following shapes were distinguished: shape $1 \mathrm{a}$ (pot), shape $1 \mathrm{~b}$ (pot with edge on uplifted flap) and shape 1c (pot with horizontal edge and flap) (Figure 11).
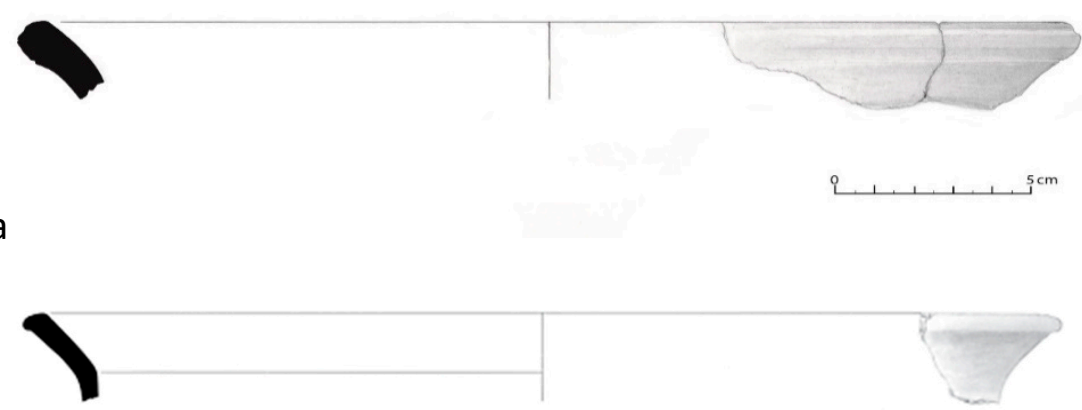

b

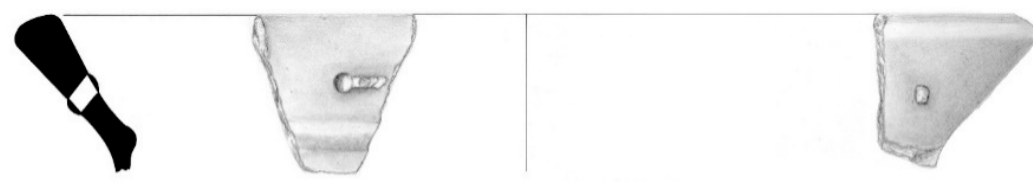

C
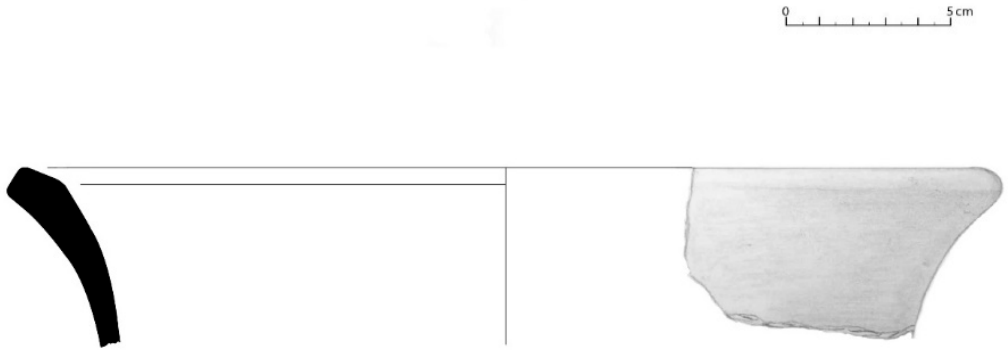

d $5 \mathrm{~cm}$

Figure 11. (a) Pot of type 1a (House 20); (b) Pot with edge on uplifted flap of type 1b. (Wall); (c) Pot in uplifted flap of type 1b, with an iron staple still preserved (House 3); (d) Pot with uplifted flap of type $1 b$ (Wall). 
For the little pots (potinhos/púcaros), shape 2 corresponded to $32 \%$ of the sample (Figures 12-15). Little pots with handle Púcaros corresponded to only $1 \%$ of the sample (Figure 16).

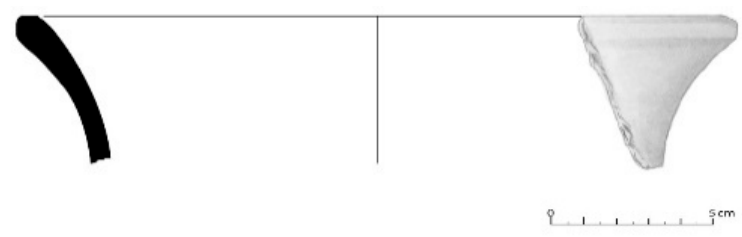

Figure 12. Little pot (potinho/púcaro) (House 3).

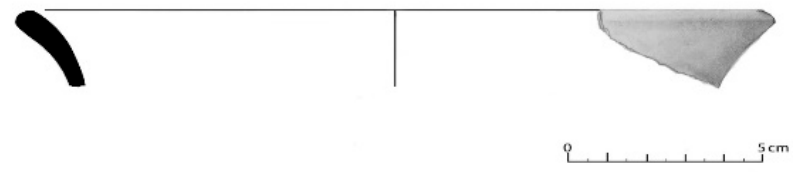

Figure 13. Little pot (potinho/púcaro) (House 20).

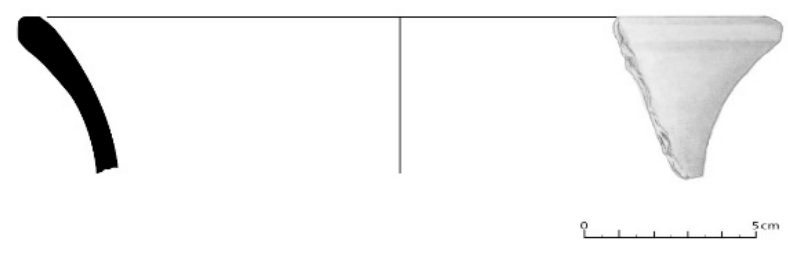

Figure 14. Little pot (potinho/púcaro) (House 2).

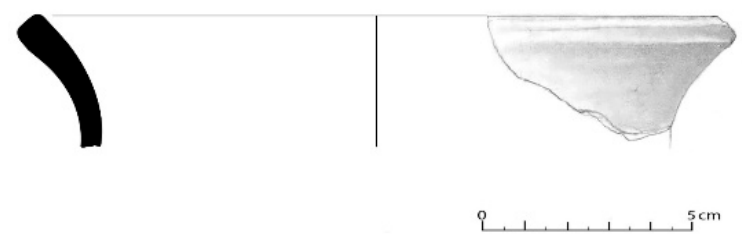

Figure 15. Little pot potinho/púcaro (House 1).

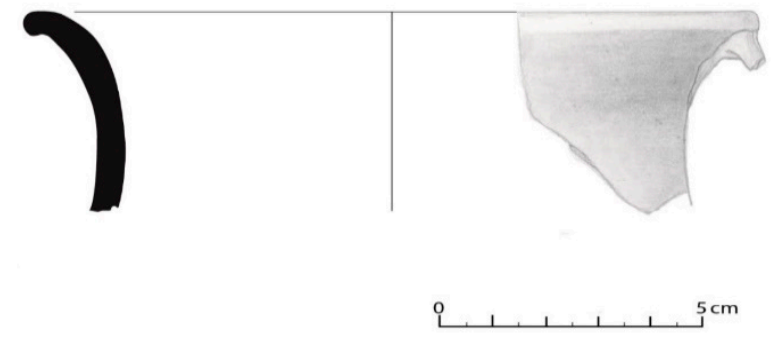

Figure 16. Little pot with handle (púcaro) (House 5).

The diameter of bowls (malgas) and little bowls (tigelas) (shapes 3) was between 15 and $30 \mathrm{~cm}$. The pot with interior handle (shape 4), which was possible to draw, had a 42-cm diameter (Figures 17-19). 


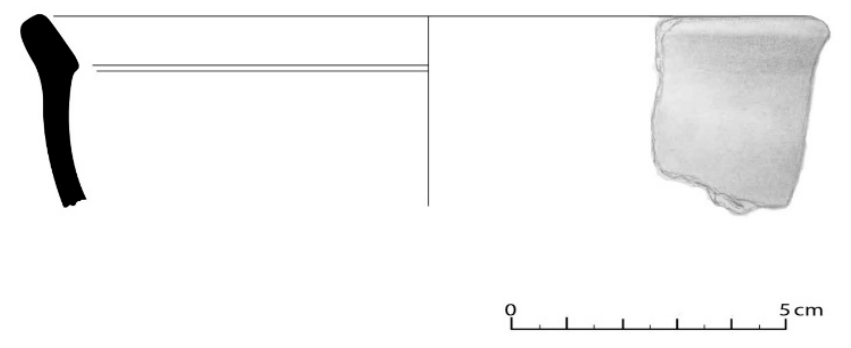

Figure 17. Bowl (tigela) (type 3a) (House 20).

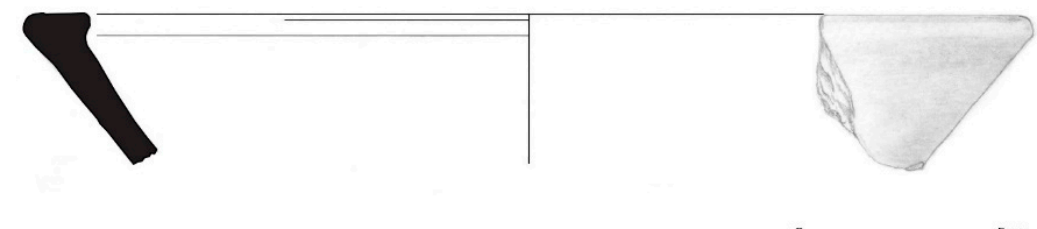

Figure 18. Little bowl (malga) (type 3b) (House 3).
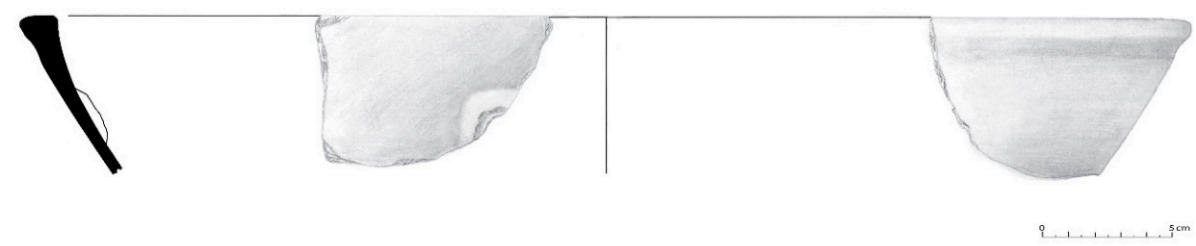

Figure 19. Pot with start of handle inside (shape 4) (House 10).

A pan with an ear handle (Panela de Asa em orelha) (shape 6) had a 23-cm diameter (Figure 20).

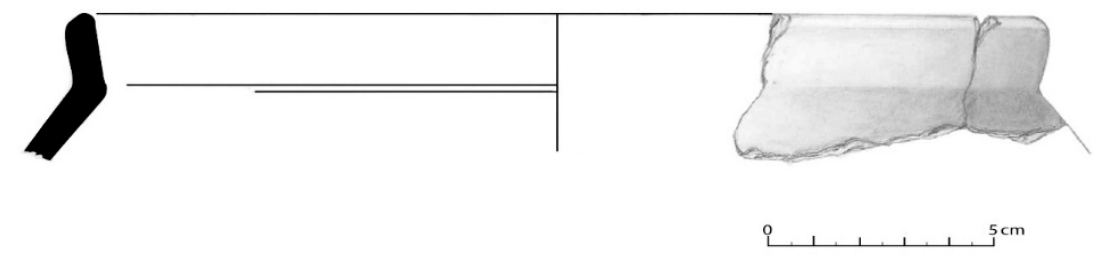

Figure 20. Pan with a, ear handle (Panela de Asa em Orelha).

Big pots (talhas) (shape 5) had a diameter between 36 and $46 \mathrm{~cm}$ (Figure 21).
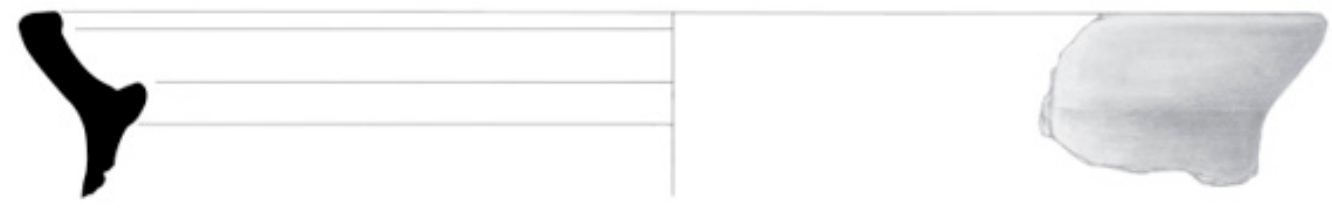

Figure 21. Big pots (talha) (House 10).

Soot appeared in 334 fragments, mostly in those which are cooking vessels, such as the pan with a ear handle and pots with handles inside, but also in some little pots, little pots with handles and bowls, indicating that some of these shapes could have been used to cook. 
Some of the vessels, such as pots with uplifted flaps and little pots, had iron staples, which only demonstrates how important it was to preserve them and the care and skill of the potters of this era (Figure 22).

The surfaces, which correspond to 91 fragments, are only of two types: simple flat bottoms and enlarged flat bottoms (Figure 23), with 40 and 15 fragments, respectively, with 36 fragments undetermined. Their diameters range from 12 to $30 \mathrm{~cm}$.
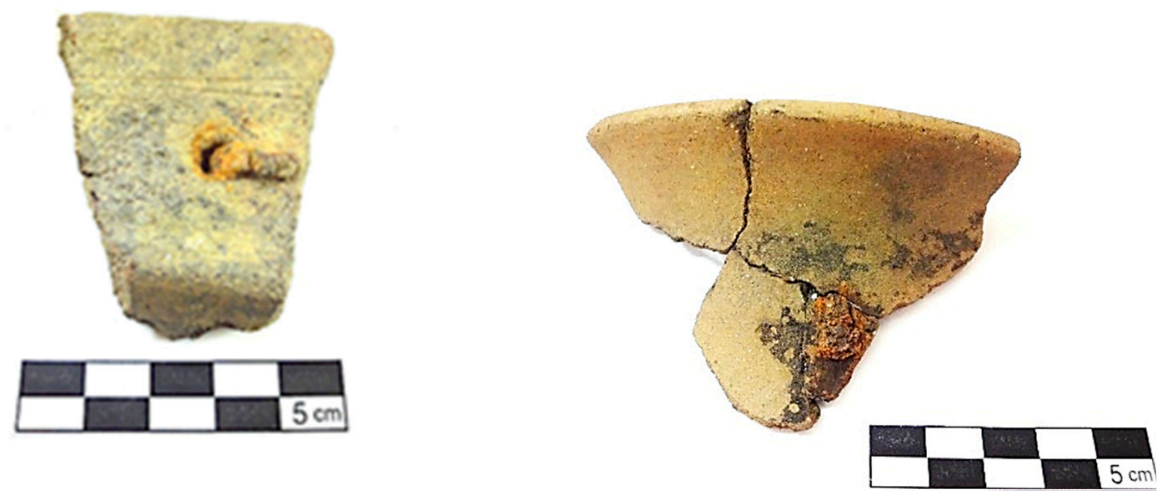

Figure 22. Fragment of the edge of a pot with uplifted flap and little pots, with preserved iron "staples".

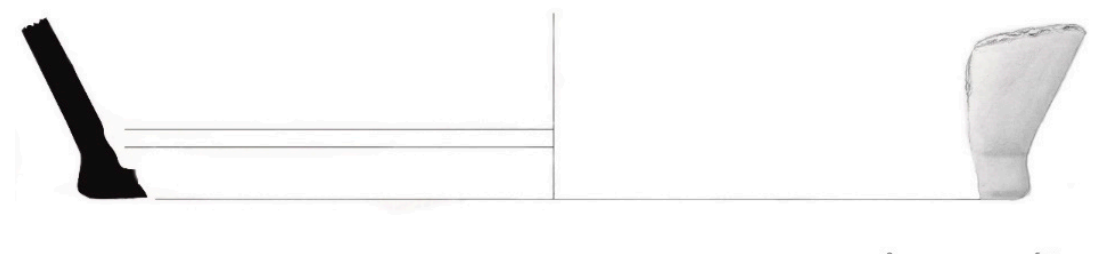

Figure 23. Surface of enlarged flat bottom found in House 5.

The handles correspond to only nine fragments, with four of a circular section and one of a subcircular section, i.e., they belong to pots with handles inside, two with horizontal gripping, belonging to a pan with a ear handle (Figure 24); one pentagonal and one rectangular or ribbon wing, most likely belonging to the little pots with handles. In House 2, a cossoiro of a biconical type with equal-sized cones was also found, according to Silva e Oliveira [8], and with central perforation (Figure 25).
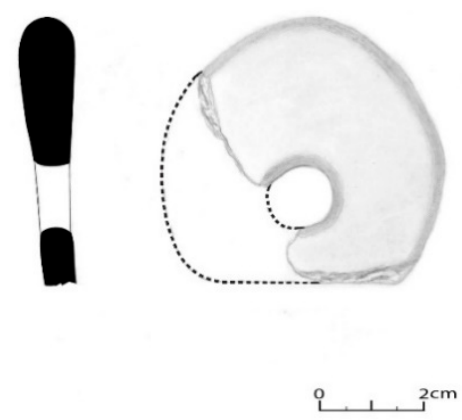

Figure 24. Ear handle (House 20). 


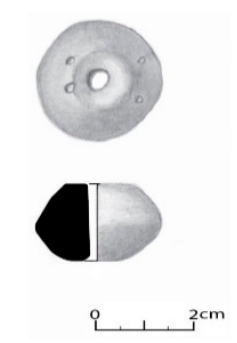

Figure 25. Cossoiro with central perforation, adorned with four small incisions.

It is also worth noting a calcined ceramic fragment was found with incrusted metal residues in the inner wall, without shape, though it might belong to a ceramic wall (Figure 26).

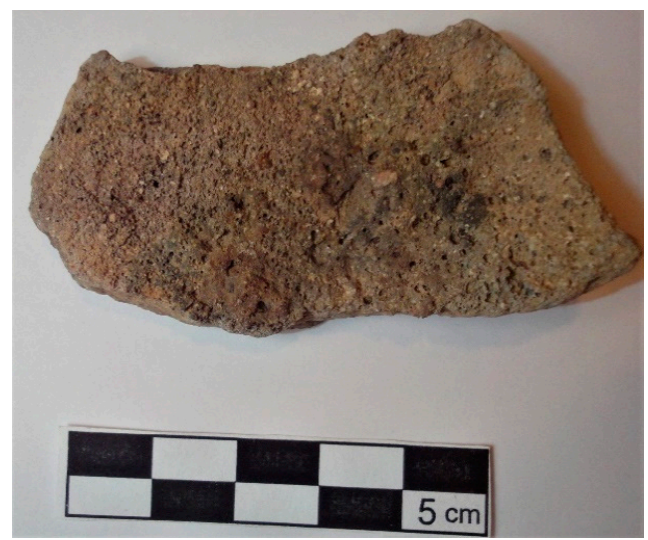

Figure 26. Fragment of ceramic wall with incrusted metal residues in the inner wall.

In the set of 1171 fragments, only $38(3 \%)$ were adorned with a variety of techniques and motifs. The prevailing technique is plastic application, seen in 14 fragments $(41 \%)$, followed by incision on 13 fragments (38\%), and two spatula-shaped fragments with dull edges. Some fragments showed composite techniques, such as incision and impression, usually horizontal, incised grooves, associated with a series of SSS (Figure 27).

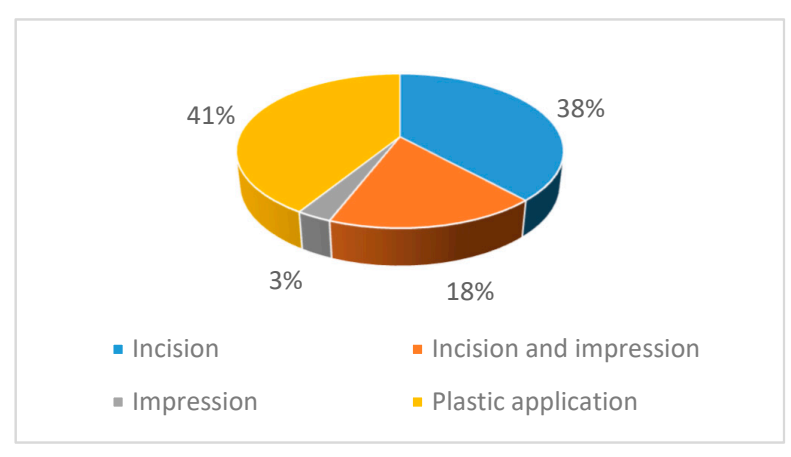

Figure 27. Percentage of decorative techniques studied.

The most common motifs are horizontal or oblique, incised grooves (sometimes carried out with dull edge objects); plastic strands and one or more series of engraved SSS (Figure 28). 
Incision
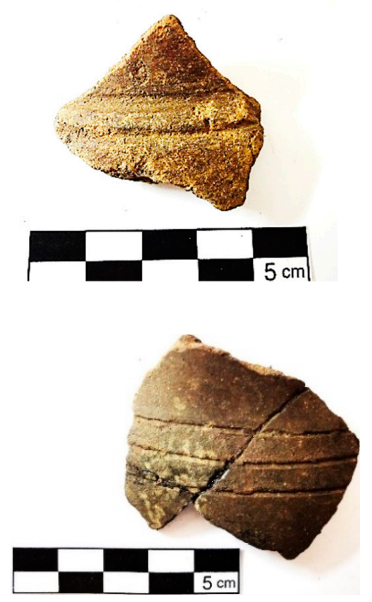

Plastic application
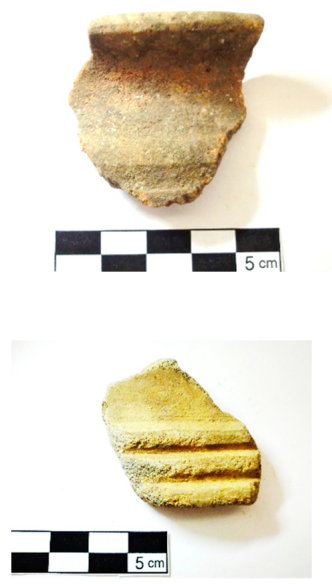

Incision and impression

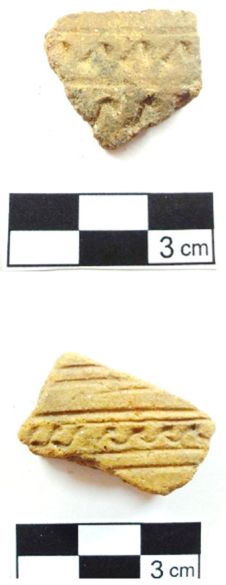

Figure 28. Example of some fragments adorned with a variety of decorative techniques.

\subsubsection{Lithic Spoil}

Lithic spoils are essentially a small elongated and amphibolite rolled pebble (We thank Vitor Hugo Torres for the lithologic classification of this pebble. This lytic was classified by microscopic analysis) and several circular millstones, with granite of thin-to-medium grains. On the surface, two moving millstones and one stationary millstone of circular shape were found [2].

\subsubsection{Spoil: Distribution in Space}

In House 1, there were a great variety of ceramic vessels, predominantly pots and little pots, two pans with an ear handle, and 1 pot with handles inside, aside from other undetermined vessels. In House 2, little pots and pots also prevailed; a cossoiro was also found. In House 3, pots and little pots prevailed as well, and a shape of pots with handles inside was found. There was a large amount of pots, followed by little pots and little pots with handle in House 5. In House 10, there seemed to be a substantial variety of vessels, where pots, little pots and a big pot can be found. In House 20, there was a prevalence of pots, little pots and one pan with a ear handle. Alongside the wall, mostly shapes of pots were found.

\section{Concluding Remarks}

Regarding the internal organization of this sector, the diversity of structures in a limited space - circular houses of varying dimensions, some with atriums and only one with opening at ground level-leads us to assume that this might have been a neighbourhood inside a walled enclosure, similar to other occurrences with other settlements of the recent Iron Age and Romanization of the Northeast, such as Citânia de Sanfins [9].

The absence of Roman tile indicates that the houses were covered with plant elements, having floors in clay. Despite the floor fragments being of medium and small size, they demonstrate that they were made with clay added to quartz and muscovite. Some had two very visible layers: the first was of preparation and the second, very thin, would correspond to the surface to walk in.

The typology and shape of the structures allows us to conclude that this is a settlement with some construction development and with residential and defensive structures, although these were severely wrecked. The analysis to the existing lithic and ceramic shapes in the residential sector suggests the development of activities related to food storage, consumption and preparation. The concentration of pots of larger size, near the wall, indicates that food storage would have prevailed there. 
The proximity of this settlement in relation to the coast, the mouth of the stream Nogueira and to Vale do Lima, to Serra de Perre, as well as to tin resources, allows to hypothesize that this would have been highly aimed to agricultural, pastoral, metallurgic and trade activities. Agricultural and pastoral activities were inferred from the ceramic spoil, with a large number of substantial size pots, and of big pots, hand mills, as well as the potential livestock buildings.

In this settlement, there were also activities related to spinning, as indicated by the cossoiro. Likewise, there were metallurgic activities, as shown by the presence of a ceramic melting wall. This is understandable given the presence of primary tin deposits in a 3-km radius (Figure 1b), although this might have existed in the alluvium of rivers Nogueira and Lima, in proximity with the settlement.

According to Queiroga [2], Roman ceramic was found in this sector, namely a large number of amphorae, which, although not studied in this work, shows a high consumption of wine and olive oil by the indigenous communities and the significant trade with the southern world, along the lower course of Lima, at the end of the first millennium BC and the beginning of the first millennium AD. Such trade was facilitated by the geographical positioning of this settlement, substantially prominent in the territory where it is found (Figure 29), which allowed the communities residing there to have a great visual control over the valley and mouth of the river. It is, therefore, to be assumed that the Romans of two millenniums ago had traveled up the river and strongly influenced the indigenous populations from this "agricultural hillfort" and took large amounts of tin and other ores.

This first analysis supports a more elaborate study, not only of this fortified settlement, but also of the Iron Age of the basin of Rio Lima in Northern Portugal.

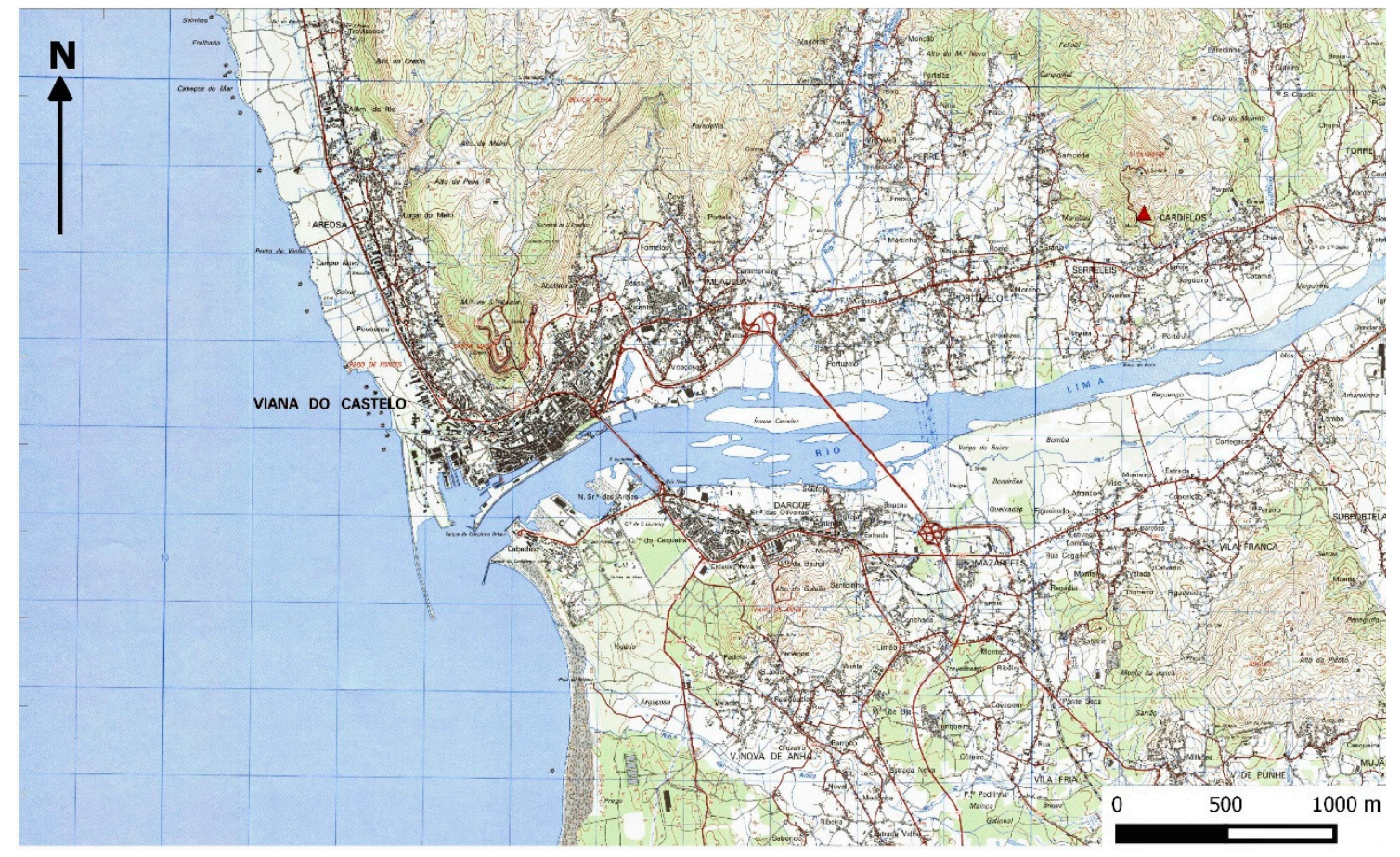

Figure 29. Context of the Terronha settlement in the Lima river basin, Portuguese Military Map, excerpt of sheet 40, scale 1:25,000, IGEOE, 2015, 3rd edition.

Funding: This research grant was funded by Fundação para a Ciência e Tecnologia (FCT), grant number [SFRH/BD/138105/2018] for my PhD scholarship.

Acknowledgments: I would like to thank Francisco Queiroga for supplying the study materials as well as for providing the documentation about the excavations. Thanks also to my friend Cristiana Ribeiro for the help in translating the text. I am deeply grateful for all the help given by Ana M. S. Bettencourt in the revision of this text.

Conflicts of Interest: The authors declare no conflict of interest. 


\section{References}

1. Almeida, C.A.B. Povoamento Romano do Litoral Minhoto Entre o Cávado e o Minho. Dissertação de Doutoramento em Pré-história e Arqueologia; Edição do Autor; Faculdade de Letras da Universidade do Porto: Porto, Portugal, 2003; Volume 7.

2. Queiroga, F. Castro da Terronha: relatório da intervenção arqueológica; Policopiado: Porto, Portugal, 2000.

3. Bettencourt, A.M.S. Gravuras rupestres da Breia, Cardielos, Viana do Castelo. In The Prehistory of the Northwestern Portugal; CHEIPAR/ARKEOS: Braga, Portugal; Tomar, Portugal, 2013; pp. 155-162.

4. Martins, M.M. A Cerâmica Proto-Histórico do Vale do Cávado: Tentativa de Sistematização; Cadernos de Arqueologia: Braga, Portugal, 1987; Volume 4, pp. 217-230.

5. Martins, M.M. O Povoamento Proto-Histórico e a Romanização da Bacia do Curso Médio do Cávado. Cadernos de Arqueologia-Monografias 5; Unidade de Arqueologia da Universidade do Minho: Braga, Portugal, 1990.

6. Ramos, C.; Martins, A. Elementos para análise e descrição de produção cerâmica. Vipasca 1992, 1, 91-102.

7. Brudenell, M.; Cooper, A. Post-middenism: Depositional histories on Later Bronze Age settlements at broom, Bedfordshire. Oxf. J. Archaeol. 2008, 27, 15-36. [CrossRef]

8. Silva, M.F.M.; Oliveira, P.C.P. Estudo tipológico dos cossoiros do Museu da Sociedade Martins Sarmento (Citânia de Briteiros, Castro de Sabroso e proveniência diversa). Revista de Guimarães 1999, Vol. Esp., II, 633-659.

9. Silva, A.C.F. A Cultura Castreja do Noroeste de Portugal; Câmara Municipal: Paços de Ferreira, Portugal, 1986.

(C) 2019 by the author. Licensee MDPI, Basel, Switzerland. This article is an open access article distributed under the terms and conditions of the Creative Commons Attribution (CC BY) license (http://creativecommons.org/licenses/by/4.0/). 